\title{
COMPARATIVE STUDIES FOR USING CERTAIN BAITS AS NATURAL CONTROL AGENT AGAINST AGROTIS YPSILON, (LEPIDOPTERA) UNDER LABORATORY AND FIELD CONDITIONS
}

\author{
El- GaRhY, S. M.M. and H. M. Ahmed \\ Plant Protection Research Institute, ARC, Dokki, Giza \\ (Manuscript received 28 December 2011)
}

\begin{abstract}
Quick lime and two other biological control agents: Bacillus thuringiensis, Metarhisium anisopliae and hostathion [triazophos] were used as poisonous pelleted semi-hard cake baits formulations contains of insecticide, sugar cane molasses and wheat brain (2: 1: 4) against the fourth instar larvae of Agrotis ypsilon. in the laboratory and the field. Quick lime was used at $1,1.2$ and $1.3 \mathrm{~kg}$, B. thuringiensis at $1 \times 10^{3}, 1.5 \times 10^{3}$ and $1.75 \times 10^{3}$ spores/ ml and Metarhisium anisopliae at $1 \times 10^{7}, 1.5 \times 10^{7}$ and $1.75 \times 10^{7}$ spores/ ml and hostathion insecticide at1, 1.5and1.75L. Double concentrations of one of the tested materials, the quick lime, bacterium, fungus and hostathion were used under field conditions. Fourth instar larvae of cut worm insect were allowed to feed on the plants treated with mixture of one of each of quick lime, microbium fungus, and hesitation and in the freely consumption (persistency) with $\mathrm{LC}_{50}$ of one of each material without plants in the laboratory in the field for 2, 4 and 6 days. Lower amout of hostathion and quick lime semi-hard cake were consumed compared with the other biological control agents and achieved higher mortality. $B$. thuringiensis and $M$. anisopliae semi-hard cake achieved moderate mortality within plants or in the freely consumptions.
\end{abstract}

\section{INTRODUCTION}

Cut-worms, Agrotis ypsilon, is well known as dangerous pest against many crops all over the world (Mishra, and Singh 2006). The insect pest often difficult to control, especially when populations are epidemic in proportion, (Hill, 1983). In Fayoum governorate, Egypt. 2009 these trials were executed to estimate and evaluate the effect of Calcium Oxide, Bacillus. thuringiensis,(Bt) and Metarhizium anisopliae as mixture in semi hard cake against the fourth instar larvae of the cut-worms compared with the chemical insecticide Hostathion [triazophos] in protecting our crops from it's severing damage. Efficiency of several pathogenic organisms, and natural and chemical materials were previously investigated against this insect (Schwarz et al 2002). The present work was concerned the evaluation the efficiency of quick lime, the pathogens bacterium, fungus and the recommended insecticide Hostathion against each of the cut-worm insect in the laboratory and field. Quick lime was one of 
the cheapest natural materials in the Egyptian desert. It was known that $\mathrm{CaO}$ reacted with water to produce $\mathrm{Ca}(\mathrm{OH}) 2$, oxygen and high energy .Quick lime used as an Eco-farming substance.

\section{MATERIALS AND METHODS}

\section{I- Laboratory studies}

\section{I-I .Stock cultures}

Stock cultures of the greasy cut worms $A$ ypsilon, additional to the entomopathogenic organisms $B$. thuringiensis, and Metarhizium anisopliae were prepared in the laboratory as fellow:

\section{a- A. ypsilon:}

Larvae of this insect were collected from the heavily infested crops of tomatoes, transferred to the laboratory and reared on tomato seedlings of 30 days old in pots of $10 \mathrm{~cm}$ for three generations (Harris et. al. 1958).

\section{b- Entomopathogenic fungi and bacterium:}

The entomopathogenic bacterium B. thuringiensis, and the fungus Metarhizium anisopliae were isolated from collected dead larvae of $A$. ypsilon, (Sabbour and Sahab 2007). Serial dilutions of the three pathogenic organisms detected and were prepared at $1 \times 10^{3}, 1.5 \times 10^{3}$ and $1.75 \times 10^{3}$ for $B$. thuringiensis, and $1 \times 10^{7}, 1.5 \times 10^{7}$ and 1.75 x $10^{7}$ for Metarhizium anisopliae. A pelleted Semi- hard cake baits formulation consisted of quick lime, sugar cane molasses and wheat bran with the rates of ( 2 $\mathrm{L}: 1 \mathrm{~L}$ :and $4 \mathrm{~kg}$ ) was prepared. The same procedures were followed for preparing the cakes mixed with any of each other materials and organisms. The experiments were carried out on tomato seedlings cultivated in plastic pots of $10 \mathrm{~cm}$. for A. ypsilon.

\section{1-2. Experimental studies:}

\section{1-2-1. Effect of quick lime:}

Ten of the fourth instars Larvae of $A$. ypsilon were introduced per plastic pot of tomato for 24 hours while the other 10 of the same age were introduced for 48 hours and 10 first instars larvae for 72 hours in cages. Each pot has one of (25gr) from the quick lime cakes individually. Quick lime was used at (1. 1.5 and $1.75 \mathrm{~kg}$ ).

\section{1-2-2. Effect of entomopathogenic fungi and bacterium:}

Ten of fourth instars larvae of $A$. ypsilon were introduced per plastic pots of tomato for 24 hours while the other 10 of the same age were introduced for 48 hours and 10 first instars larvae for 72 hours in cages. Each pot has ( $25 \mathrm{gr}$.) of each of the previous cakes individually. The researchers quantified the effects of sub lethal concentration( $\mathrm{LC}_{50}$ ) of quick lime and other sub lethal rates of the microbial organisms and 
hostathion on a number of $A$. ypsilon fitness parameters. A new cakes of the bacterium and fungi were prepared for estimating the freely consumption of the fourth instar larvae of $A$. ypsilon by mixing the sub lethal by the same abovementioned ratio and introduced in Petri dishes, each has five of the fourth instar larvae of A.ypsilon. Avoiding cannibalism, each two Petri dishes represent one replicate. Daily consumption of the insect was calculated.

\section{1-2-3. Effect of hostathion [triazophos] insecticide:}

Ten of fourth instars larvae of $A$._ypsilon were introduced per plastic pots of tomato for 24 hours while the other 10 of the same age were introduced for 48 hours and 10 first instars larvae for 72 hours in cages. Each pot has one of the studied poisonous cakes individually. Sub Lethal concentration $\left(\mathrm{LC}_{50}\right)$ of hostathion were calculated. A new pelleted poisonous semi-hard cakes of hostathion were prepared by mixing the sub lethal by the same mentioned ratio. and introduced in Petri dishes, each has 5 of the fourth instar larvae of $A$.ypsilon. For avoiding cannibalism every two dishes represent one replicate Daily consumption of the insect pest was calculated.

\section{2-Field trials}

Under the field conditions the area was divided into four replicates each has four beds $(1 \times 3 \mathrm{~m})$. Double concentrations were used as follow: pelleted quick lime semi-hard cakes (2, 3 and $3.4 \mathrm{~kg}), B$. thuringiensis and M. anisopliaee were used at $\left(2 \times 10^{3}, 3 \times 10^{3}\right.$ and $\left.3.5 \times 10^{3}\right)$ and hostathion $(2,3$ and $3.5 \mathrm{~L})$ per each plot and control distributed randomly. The plot bedes were transplanted by Castle rock tomato from Peto Seed Co. Each bed was planted from both sides at distances of $10 \mathrm{~cm}$ and covered by black shade netting. 10 of the fourth instar larvae of $A$. ypsilon were introduced per bed. Semi-hard cake of the mixture of the quick lime and molasses were applied on the beds at distances of $25 \mathrm{~cm}$ beside plants. Each of other mixtures of the pathogenic fungus, bacterium and the hostathion were added on beds. The field of the trial was inspected every 2, 4 and 6 days. Dead larvae of $A$. ypsilon were collected in paper pages and transferred to the laboratory.

\section{3- Statistical analysis:}

The data were analyzed using probit analysis (Finny, 1952) and $L_{50}$ values were estimated for each of tested material, bioagentsand chemical insecticide. Statistical calculator was don through SPSS 11 for windows computer program to determine the Correlation and Regression Co-Efficient $(r)$. 


\section{RESULTS AND DISCUSSION}

As shown in table (1) and Figs (1,2 and 3)the obtained results indicated that the dead counts of $A$. ypsilon after 24, hr were 6.3, 7.3 and 8.6 from 10 fourth instar larvae introduced and fed on the pelleted semi-hard cake bait at of $1,1.5$, and 1.75 $\mathrm{kg}$ of the quick lime, respectively. Larvae were consumed on 2.5. 2.3 and $1.8 \mathrm{gr}$., other dead counts of $A$. ypsilon fourth instar larvae after 48, hr were 7.0, 7.5 and 8.7 were fed on the semi-hard cake of the quick lime. Calculated grams of the semi-hard cake of the quick lime were 2.6, 2.1 and 1.8, resp. Dead larvae after $72 \mathrm{hr}$. Were 7.5, 8.0 and 9.0 fed on the semi-hard cake of the quick lime of $1,1.5$ and $1.7 .5 \mathrm{~kg}$. were 2.6, 2.0 and 1.8 grams, respectively. Dead counts of the fourth instar larvae were 0.0 in the control and calculated grams that were consumed were 5.0, 7.5 and 10.5 resp. Calculated $\mathrm{LC}_{50}$ were $0.890,0.760$ and 0.720 after 24,48 and $72 \mathrm{hr}$.

Table (1) and Figs (1,2 and 3): shows that the dead fourth instar larvae with the concentrations of $1 \times 10^{3}, 1.5 \times 10^{3}$ and $1.75 \times 10^{3}$ of $B$. thuringiensis under the laboratory conditions after 24, 48 and $72 \mathrm{hr}$ were 6.1, 6.4 and6.8 and 6.5, 6.6 and 7.5 and 6.8, 7.0 and 8.5 and the control 0.0 resp. However, (Atalla et a/ 2001) reported that the total mortality of the aforementioned insect pest were $27-80$ on the $2^{\text {nd }}$ and $4^{\text {th }}$ insrar larvae after spraying Agrin, Bacillus thuringiensis the bioinsecticide on the tomato plants. Calculated $\mathrm{LC}_{50}$ for the abovementioned concentrations were $4.2 \times 10^{2}$, $4.1 \times 10^{2}$ and $4.0 \times 10^{2}$. (Mansour et al 2005) tested a biocide containing $20 \%$ delta endotoxin of Bacillus thuringiensis var. kurstaki at 100, 200, 400, 800 and 1600 ppm against $4^{\text {th }}$ instar larvae of $A$. ipsilon fed on toxicant bait. Calculated $\mathrm{LC}_{50}$ values $72 \mathrm{~h}$ post treatment with MVP were $480.2 \mathrm{ppm}$ for $4^{\text {th }}$ instar larvae.

Table (1) and Figs (1,2 and 3): shown that the consumption of the abovementioned poisonous semi-hard cake of $B$. Thuringiensis after 24,48 and $72 \mathrm{hr}$. were 3.9,4.1and 4.1and 4.5, 4.6 and 4.4 and 5.1, 5.2 and 5.0 grams while consumed grams by the fourth instar larvae in the control were 5.1, 7.8 and 10.0. Table (1) and Figs (1,2 and 3): shows that dead fourth instar larvae with the concentrations of $M$. anisopliae $\left(1 \times 10^{7}, 1.5 \times 10^{7}\right.$ and $\left.1.75 \times 10^{7}\right)$ semi-hard cake after 24,48 and $72 \mathrm{hr}$ were 6.0, 6.4 and 6.5 and 6.3, 6.5 and 6.7 and 6.5, 6.8 and 8.0 resp. The dead Counts of the fourth instar larvae in the control were 0.0 . Calculated $L C_{50}$ were $3.5 \times 10^{6}, 1.6 \times 10^{6}$ and $1.5 \times 10^{6}$. Table (1) and Figs (1,2 and 3), shows that the consumption of the fourth instar larvae after the same abovementioned period (24, 48 and $72 \mathrm{hr}$ ) were 4.0, 4.1 and 4.2 and 4.6, 4.8 and 4.7 and 5.6, 5.7 and 5.5gr.Table (1): shows that calculated consumption of the fourth instar larvae in the control were 5.2, 8.0 and $10.8 \mathrm{gr}$. The dead larvae with poisonous semi-hard cake of hostathion pesticide with the concentrations of $1,1.5$ and $1.75 \mathrm{~L}$ after (24, 48 and72) were 6.2, 6.5 and 7.3 and 7.0, 7.5 and 7.8 and 7.5, 8.3 and 9.0 and 0.0 in the control. Calculated $L C_{50}$ was 
$0.735,0.650$ and 0.600 . Calculated consumption in grams of the fourth instar larvae after the abovementioned hours (24, 48 and 72 ) were $1.9,1.7$ and 1.5 and $2.1,1.7$ and 1.5 and 2.2, 1.8 and 1.5 while in the control 5.1, 8.2 and 10.2 grams. Table (2): shows that the dead counts of the $A$. ypsilon freely consumed on semi-hard cake with the concentrations of $\left(\mathrm{LC}_{50}\right)$ of the quick lime semi hard cake after 24,48 and $72 \mathrm{hr}$ were 3.1, 4.2 and 5.1 and 3.4, 4.5and 5.2 and 4.1, 5.4 and 6.4 and the control was 0.0 resp. Registered grams of the semi-hard cake consumed after the abovementioned times under the laboratory conditions were 4.5, 4.3 and 4.7 and 3.8 and 6.4, 4.1and 3.8 and $4.7,4.1$ and 3.8. Ferthermore, the quantities of the semi-hard cake in the control were 10.5, 12.2 and 15.5 resp. Table (2) and Figs (4,5 and 6): shows that the dead fourth instar larvae freely consumed on the concentrations of $\left(\mathrm{LC}_{50}\right)$ of B.thuringeinsis semi hard cake after the abovementioned times $(24,48$ and $72 \mathrm{hr}$ ) were 3.1, 3.1 and 3.3 and 3.2, 3.3 and 3.4 and 3.4, 3.4 and 4.2 and 0.0 control under the laboratory conditions resp. Table (2) shows that calculated dead fourth instar larvae in freely consumptions of the poisonous semi hard cakes of M. anisopliae in grams after the abovementioned times (24, 48 and $72 \mathrm{hr}$ ) were 3.0, 3.0 and 3.2 and $3.1,3.2$ and 3.5 and5.2, 3.3 and 4.0 while in the control 10.1, 14.3 and 15.5 resp. Table (2) shows that calculated freely consumptions of the fourth instar larvae on M. anisopliae semi hard cakes after (24, 48 and $72 \mathrm{hr}$ ) were 5.2, 5.3 and 6.2 and 5.7, 5.8 and 8.7 and 5.8, 6.7 and 8.4 and 10.2, 12.1 and 15.2 grams in the control. Table (2) shows that dead fourth instar larvae in the freely consumptions fed on the hostathion semi hard cake after (24, 48 and $72 \mathrm{hr}$ ) were $3.1,3.3$ and 4.3 and 3.3, 3.5 and 4.0 and 3.4, 4.1 and 4.5 and 10.1, 12.1 and 15.2 grams in the control resp. Calculated grams after the previous mentioned times (24, 48 and $72 \mathrm{hr}$ ) were 2.8, 2.5 and 2.5 and 4.2, 2.6 and 2.6 and 4.3, 2.6 and 2.6. Table (3) and figs (4,5 and 5): shows that dead fourth instar larvae fed on the quick lime semi hard cake after $(2,4$ and 6 days) were 4.5, 5.0 and 5.0 and 6.0, 6.0 and 6.0 and 6.3, 7.3 and 7.5 and 0.0 control under the field conditions. (Aditi Badiyala and Sharma, D. C 2007) found that $B$. thuringiensis at the concentration of $3.96 \times 10^{7} \mathrm{IU} /$ ha was superior in suppressing the aforementioned pest over the untreated control. Under the field conditions, Table(3): shows that the dead counts of fourth instar larvae fed on the poisonous $B$. thuringiensis semi hard cake after (2, 4 and 6 days) were $0.0,0.0$ and 0.0 and 3.5, 4.5 and 5.3 and 4.0, 4.8 and 6.5 and 0.0 in the control. (Amitava Konar et a/ 2003) reported that $M$. anisopliae by the concentration of $1 \times 10^{8}$ spores / $\mathrm{ml}$ was the most effective on the fourth instar larvae. Other fourth instar larvae fed on the poisonous semi hard cake with $M$. anisopliae after the previous days (2, 4 and 6 days) were 0.0 with the three concentrations and 3.0, 4.4 and 5.0 and 3.5, 4.8 and 6.3 and 0.0 in the control. The counts of the dead larvae fed on the poisonous semi hard cake with the chemical insecticide hostathion at (2, 4 and 6 days) were 3.0, 4.5 and 5.5 and 4.0, 5.5 
and 6.5 and 5.0, 5.5 and 7.5 and 0.0 in the control. Tables (1, 2, and 3) shown that the quick lime and the pesticide hostation achieved higher mortality within tomato plants and freely consumption than other bacterium $B$. thuringiensis, the fungus $M$. anisopliae after 24,48 and $72 \mathrm{hr}$ by the abovementioned concentrations. However, Insecticides were used in wide range against $A$. ypsilon in the field allover the world however, the hazards of using the insecticides were recorded in several researches (Badenes-Perez et a/ 2006). In (2002) (Muhammad Shakur et al) reported that using baits of (Dipterex [trichlorfon] + sugar + rice husk) on permanent plots of potato crop for controlling the above-mentioned insect pest were effective and more persistent for giving healthy products. (Salama et al 1999) studied the possiblility of using $B$. thuringiensis (B.t) preparation (Dipel $2 \mathrm{X}$ ) as a substitute for chemical insecticides (Lannate [methomyl] and Hostathion [triazophos]) was evaluated against A. ypsilon the major pest of potato, and reported that both biopesticide and chemical insecticides were effective against the target insect and reported that one spray or bait application of Dipel $2 X$ at the rate of $750 \mathrm{gm} /$ feddan provided a satisfactory protection of the potato crop against infestation with $A$. ipsilon. The same auther et al (1995) add that When B.t. baits were used, the percentage mortality of A.ypsilon reached 96.1-96.4 compared with 97.4-98.0 when using hostathion [triazophos] baits in soybean. And in (1990 et a/ the same other) studied the effective threshold rate of application of Dipel 2X (Bacillus thuringiensis subsp. kurstaki) against Agrotis ipsilon on vegetable crops and reported that the incorporation of some chemical additives such as calcium sulfate or calcium oxide significantly potentated the effectiveness of the microbial pesticide on larval populations. Therefore, the quick lime was used for the first time is an efficient bait for controlling the the fourth instar larvae of $A$. ypsilon. (Youssef, 1997), tested common alum, aluminum potassium sulfate (solid) and aluminium oxide (liquid) as poison baits in laboratory experiments against $A$. ipsilon one-day-old sixth-instar larvae, however the solid and liquid were also tested as synergists of recommended insecticides (Hostathion [triazophos]therefore, all cases mortality was more than $80 \%$. Hostathion insecticide was used in bait for controlling A. ypsilon, an additional problem for control is the soil dwelling habits of the larvae, often beneath heavy foliage, making it difficult for insecticides to reach their targets (Hill 1983). But its persistency polluted the soil for long time after spraying. Therefore, Quick lime and Hostathion B. thuringiensis, M. anisopliae achieved higher mortality after $72 \mathrm{hr}$ in the laboratory and 6 days in the field Respectively. Furthermore, quick lime was safety and cheap to the farmers in controlling the abovementioned insect pest. Statistical analysis shows that the correlation and regression co-efficient were $(r$ $=0.5$ ) 
Table 1. Efficiency of poisonous cakes of the quick lime, B.thuringiensis, M.anisopliae and hostathion insecticide semi- hard cake and Quantities (in grams) consumed per 10 fourth instar larvae on tomato plants after 24,48 and $72 \mathrm{~h}$. in the laboratory.

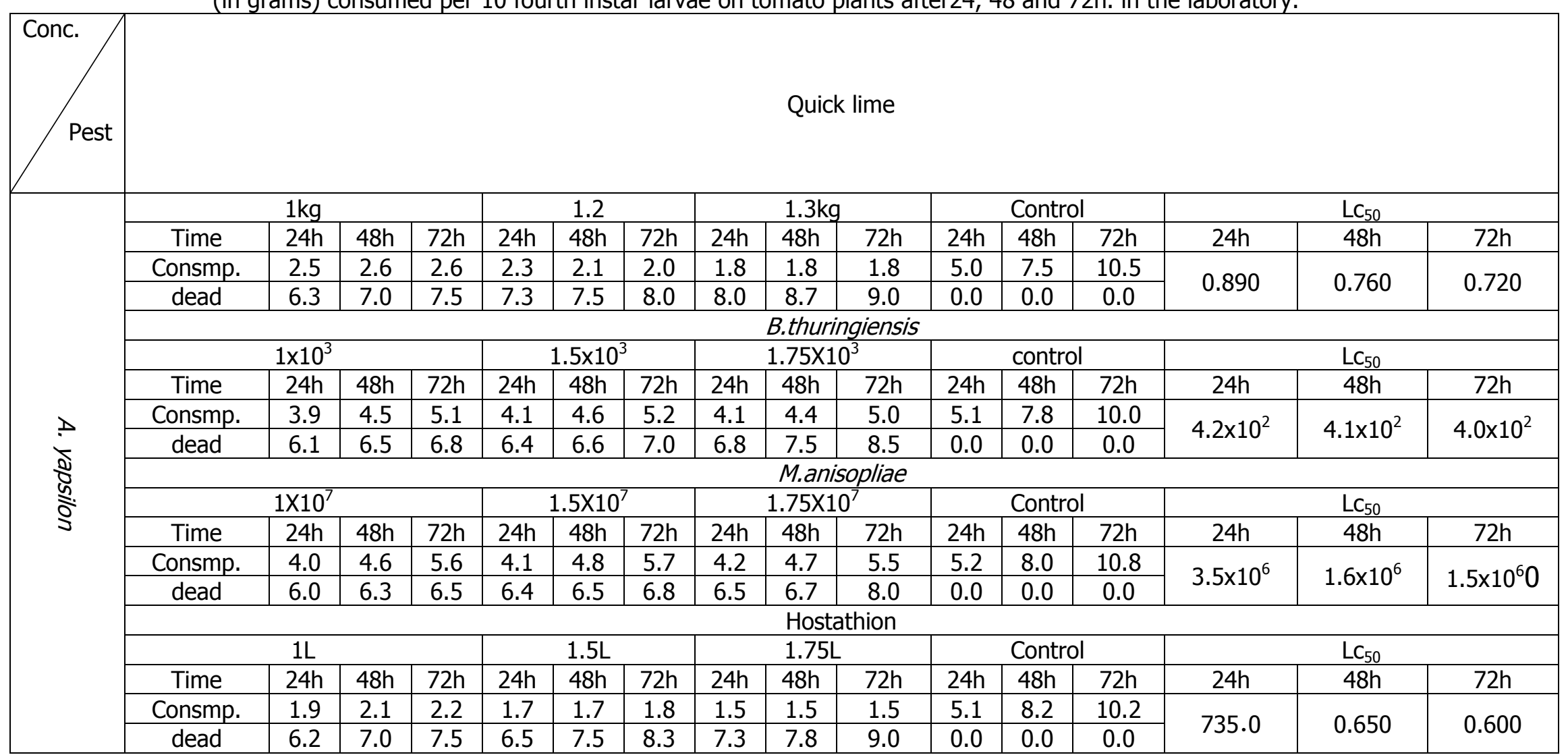

N.B: Quantities consumed per 10 fourth instar larvae exposed

Consmp. .: consumption 
Table 2. Efficiency of the poisonous semi-hard cake of quick lime, B.thuringiensis, M.anisopliae and hostathion insecticide (in grams) at (LC $\left.\mathrm{C}_{50}\right)$ Freely consumption per 10 fourth instar larvae after 24,48 and $72 \mathrm{hr}$. in the laboratory.

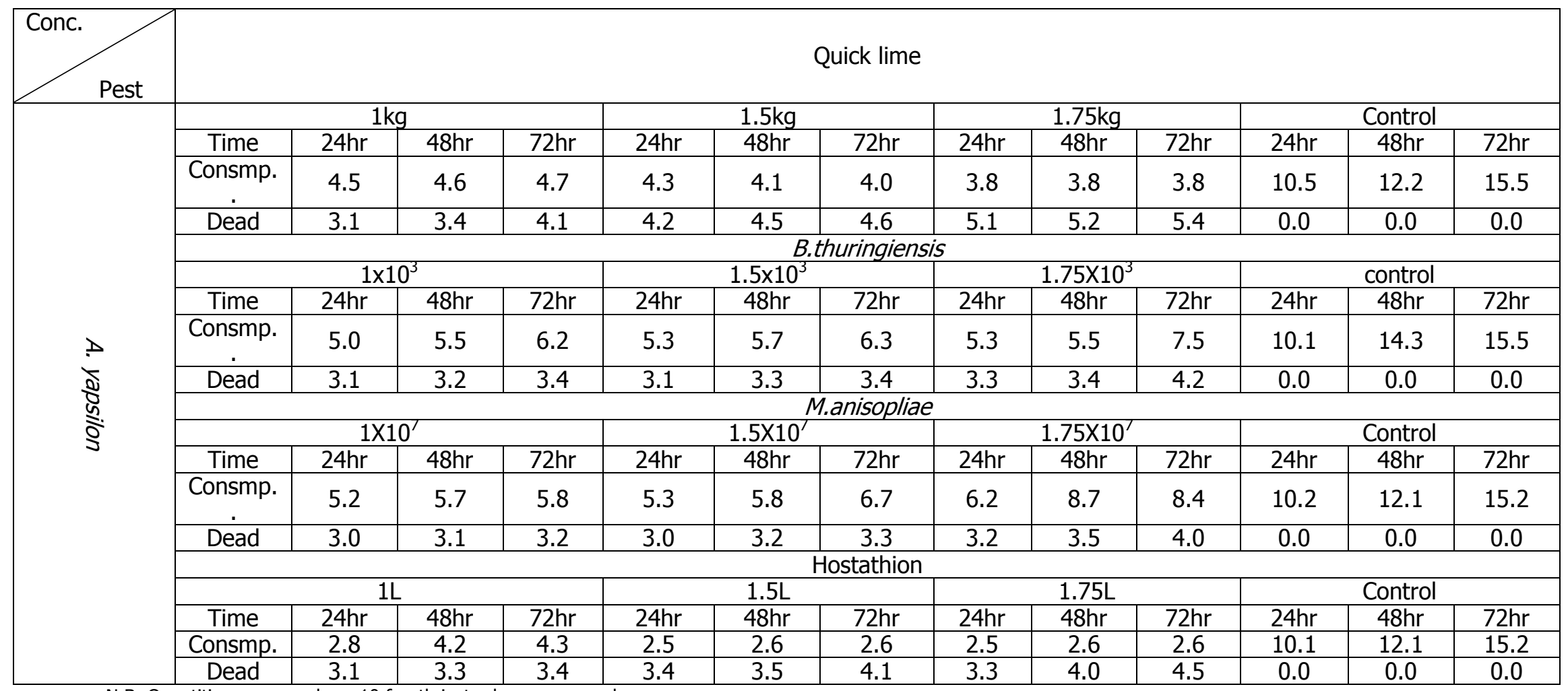

N.B: Quantities consumed per 10 fourth instar larvae exposed.

Consmp..: consumption 
Table 3. Efficiency of the poisonous semi-hard cake of Quick lime, B.thuringiensis, M.anisopliae and hostathion insecticide on the fourth instar larvae of $A$. yapsilon within tomato after 2,4 and 6 days in the field.

\begin{tabular}{|c|c|c|c|c|c|c|c|c|c|c|c|c|}
\hline Conc. & & & & & & & ick lime & & & & & \\
\hline \multirow{15}{*}{ 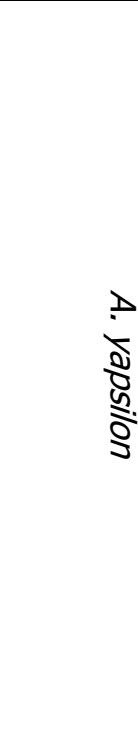 } & \multicolumn{3}{|c|}{$2 \mathrm{~kg}$} & \multicolumn{3}{|c|}{$3 \mathrm{~kg}$} & \multicolumn{3}{|c|}{$3.4 \mathrm{~kg}$} & \multicolumn{3}{|c|}{ Control } \\
\hline & 2days & 4 days & 6 days & 2days & 4 days & 6 days & 2days & 4 days & 6 days & 2days & 4 days & 6 days \\
\hline & 4.5 & 6.0 & 6.3 & 5.0 & 6.0 & 7.3 & 5.0 & 6.0 & 7.5 & 0.0 & 0.0 & 0.0 \\
\hline & \multicolumn{12}{|c|}{ B.thuringiensis } \\
\hline & \multicolumn{3}{|c|}{$2 \times 10^{3}$} & \multicolumn{3}{|c|}{$3 \times 10^{3}$} & \multicolumn{3}{|c|}{$3.5 \times 10^{3}$} & \multicolumn{3}{|c|}{ control } \\
\hline & 2days & 4 days & 6 days & 2days & 4 days & 6 days & 2days & 4 days & 6 days & 2days & 4 days & 6 days \\
\hline & 0.0 & 3.5 & 4.0 & 0.0 & 4.5 & 4.8 & 0.0 & 5.3 & 6.5 & 0.0 & 0.0 & 0.0 \\
\hline & \multicolumn{12}{|c|}{ M.anisopliae } \\
\hline & \multicolumn{3}{|c|}{$2 \times 10^{7}$} & \multicolumn{3}{|c|}{$3 \times 10^{7}$} & \multicolumn{3}{|c|}{$3.5 \times 10^{7}$} & \multicolumn{3}{|c|}{ Control } \\
\hline & 2days & 4 days & 6 days & 2days & 4 days & 6 days & 2days & 4 days & 6 days & 2days & 4 days & 6 days \\
\hline & 0.0 & 3.0 & 3.5 & 0.0 & 4.4 & 4.8 & 0.0 & 5.0 & 6.3 & 0.0 & 0.0 & 0.0 \\
\hline & \multicolumn{12}{|c|}{ Hostathion } \\
\hline & \multicolumn{3}{|c|}{$2 \mathrm{~L}$} & \multicolumn{3}{|c|}{$3 \mathrm{~L}$} & \multicolumn{3}{|c|}{$3.5 \mathrm{~L}$} & \multicolumn{3}{|c|}{ Control } \\
\hline & 2days & 4 days & 6 days & 2days & 4 days & 6 days & 2days & 4 days & 6 days & 2days & 4 days & 6 days \\
\hline & 3.0 & 4.0 & 5.0 & 4.5 & 5.5 & 6.5 & 5.5 & 6.5 & 7.5 & 0.0 & 0.0 & 0.0 \\
\hline
\end{tabular}

N.B: Dead counts per 10 fourth instar larvae exposed. 


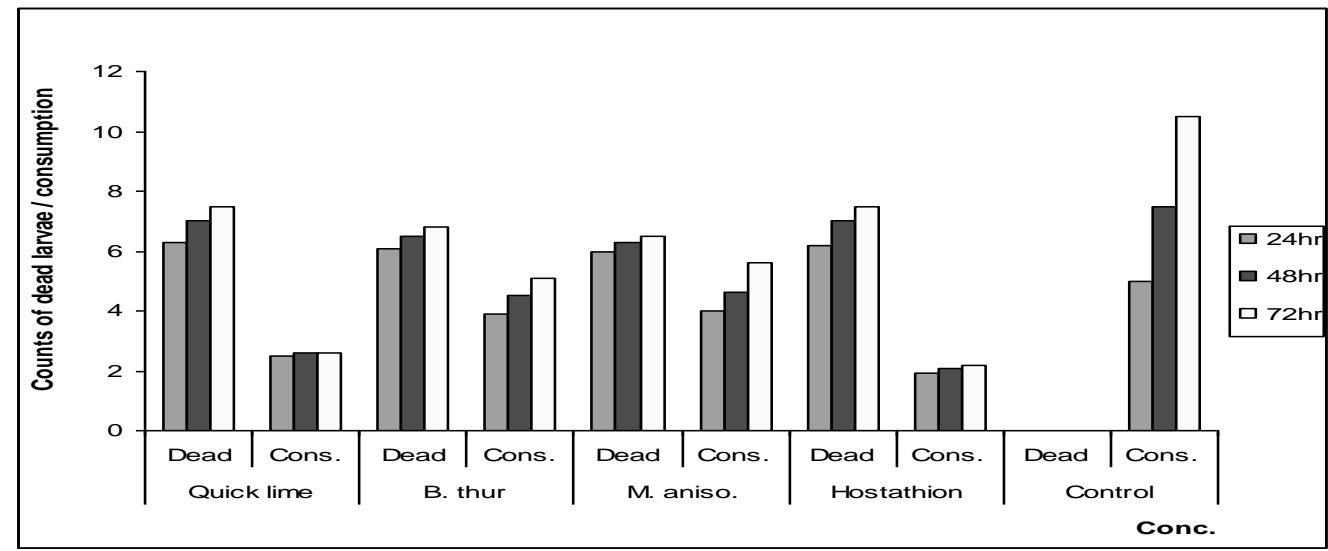

Fig. 1. Efficiency of quick lime, B. thuringiensis, M. anisopliae and hostathion and consumed quantitis on the fourth instar larvae of $A$. ypsilonin in the loboratory.

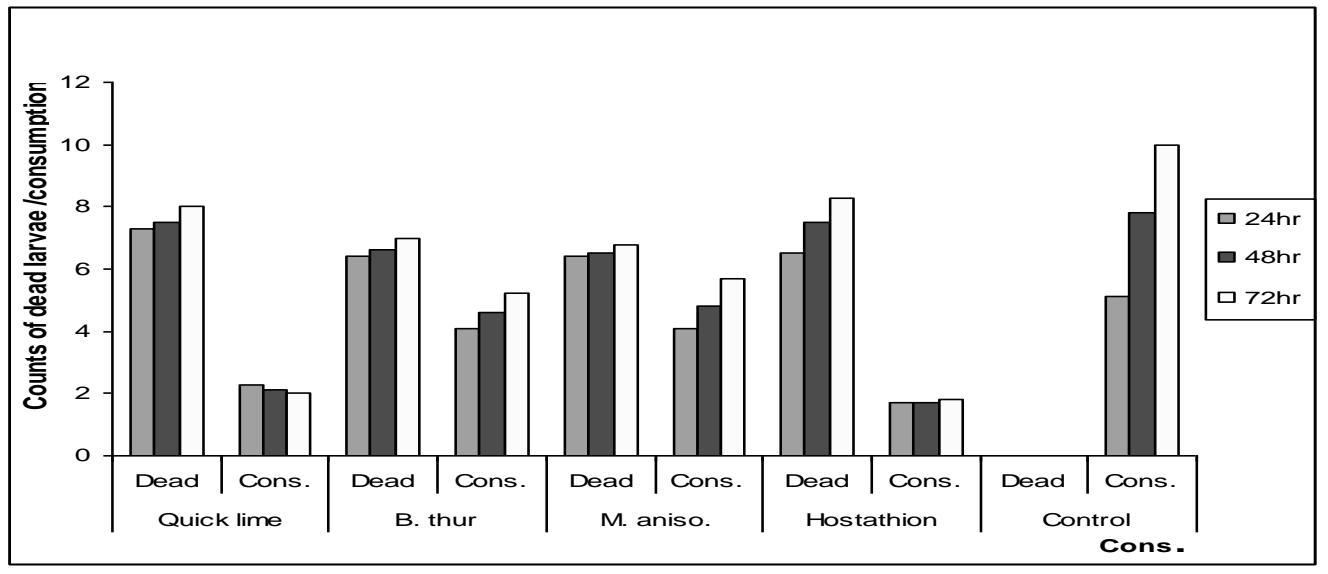

Fig. 2. Efficiency of quick lime, B. thuringiensis, M. anisopliae and hostathion and consumed quantitis on the fourth instar larvae of $A$. ypsilonin in the loboratory. 


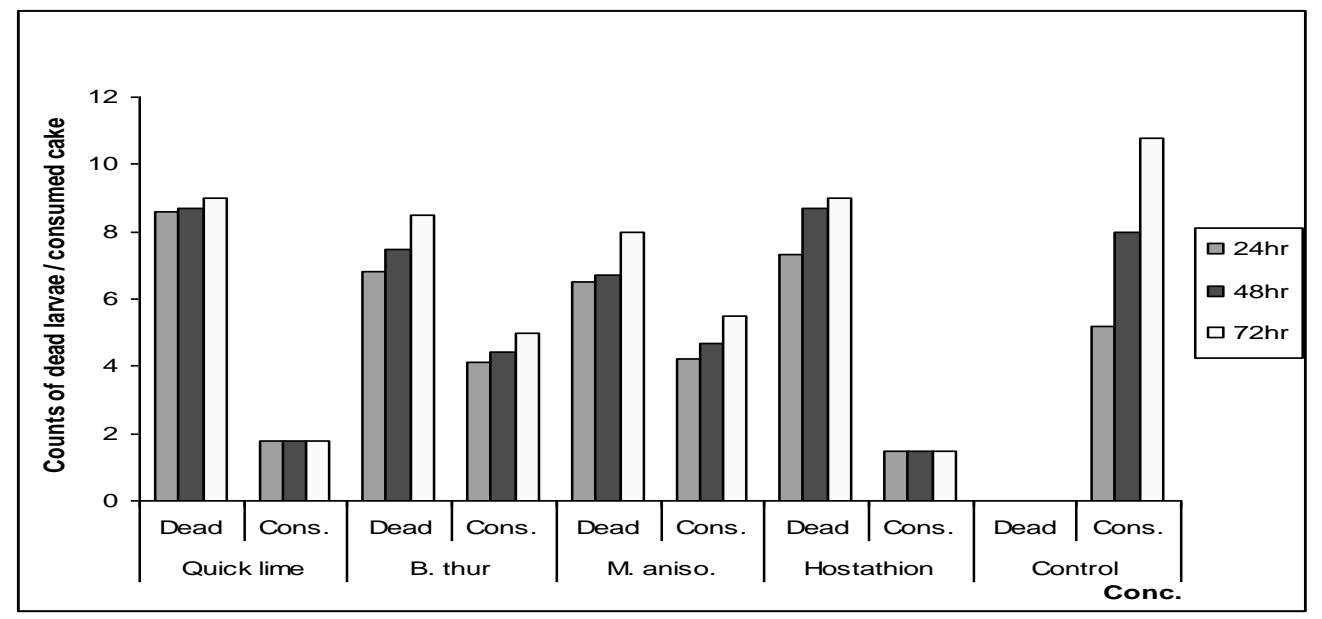

Fig. 3. Efficiency of quick lime, B. thuringiensis, M. anisopliae and hostathion and consumed quantitis on the fourth instar larvae of $A$. ypsilonin in the loboratory.

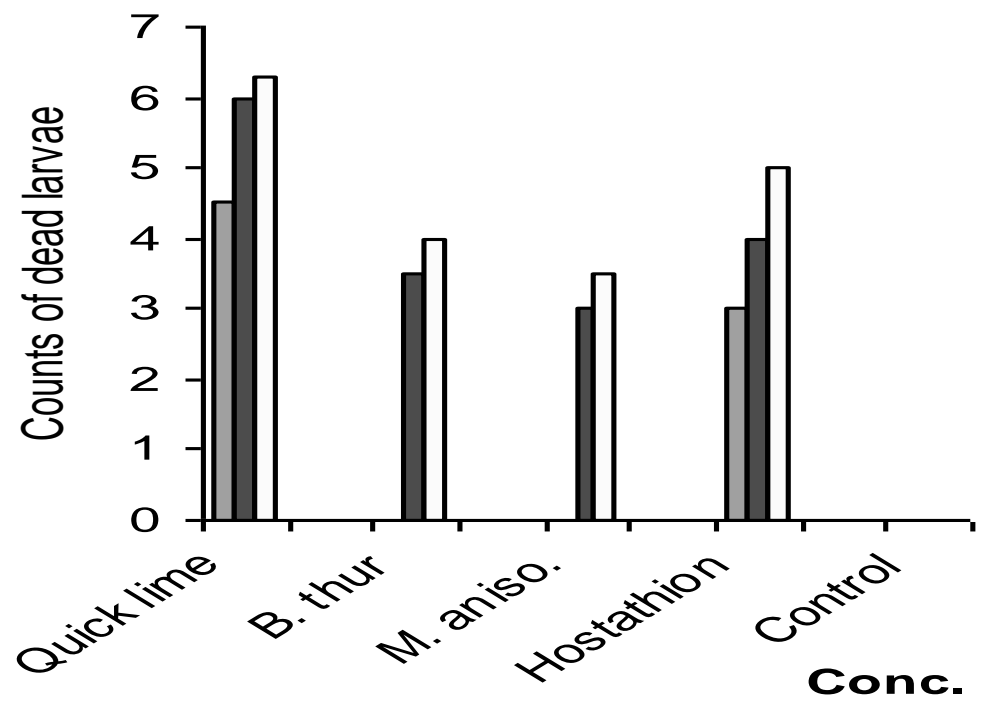

Fig. 4. Efficiency of quick lime $B$. thuringiensis, M. anisopliae and Hostathion on the fourth instar larvae of $A$. yabsilon, in the field. 


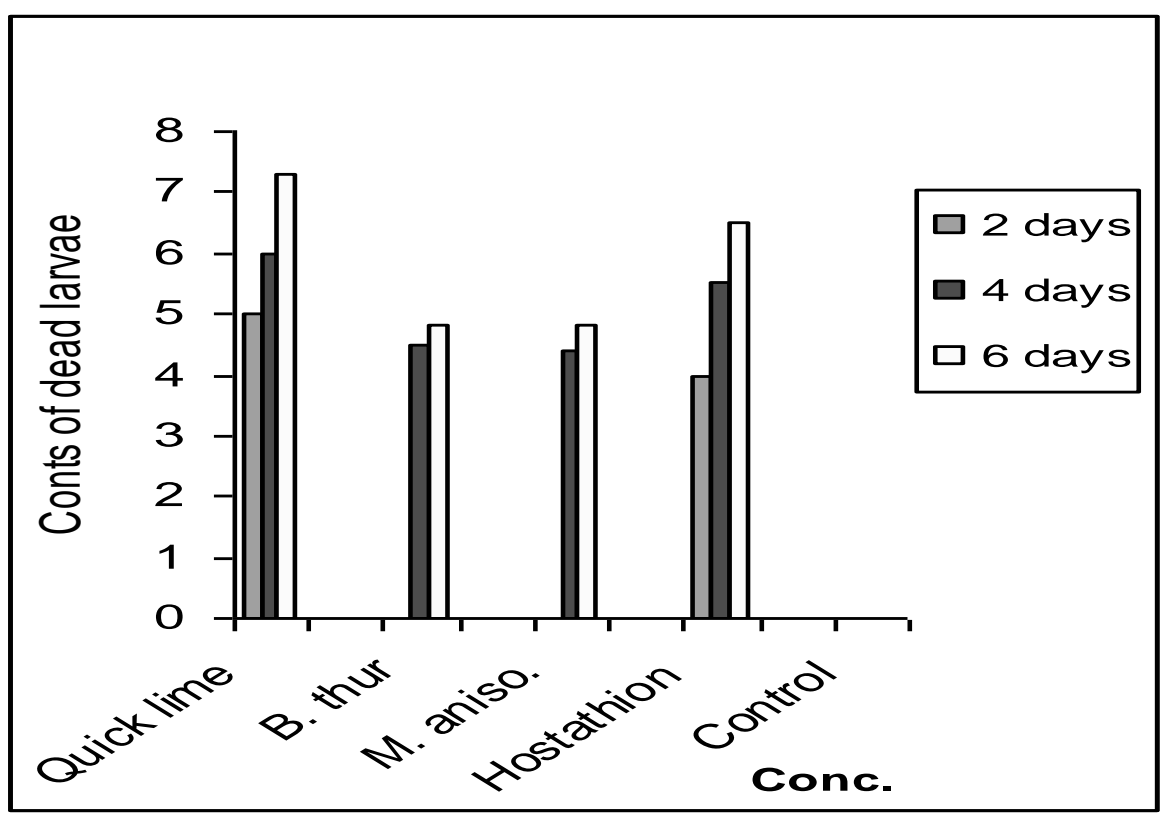

Fig. 5. Efficiency of quick lime $B$. thuringiensis, M. anisopliae and Hostathion on the fourth instar larvae of $A$. yabsilon in the field.

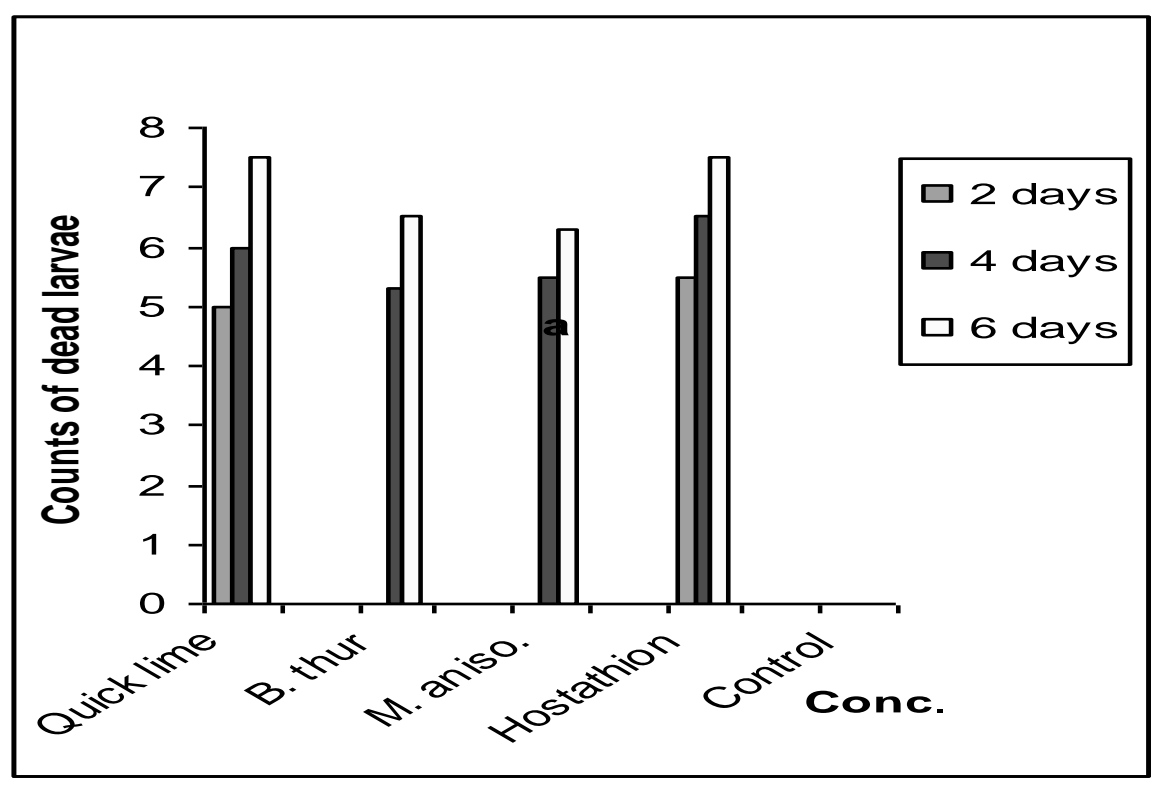

Fig. 6. Efficiency of quick lime $B$. thuringiensis, M. anisopliae and Hostathion on the fourth instar larvae of $A$. yabsilon in the field 


\section{REFERENCES}

1- Aditi Badiyala and D. C. Sharma. 2007. Bioefficiancy and persistent toxicity of some biopesticides and insecticides against cutworm, Agrotis ipsilon Hufner on spring potato. Pesticide Research Journal. 2007. 19: 1, 37-41. 20 ref India.

2- Amitava Konar, Santanu Paul, A. Basu, M. Chettri. 2003. Field evaluation of biopesticides and insecticides against cutworm in plains of West Bengal. Journal of the Indian Potato Association. 2003. 30: 1/2, 155-156. 5 ref India.

3- Atalla, F. A., A. A. El-Zoghby, M. A. Eweis. 2001. Susceptibility of the three lepidopterous pests, Sesamia cretica (Led.), Spodoptera littoralis (Boisd.) and Agrotis ipsilon (Hufn.) to the bacterial biocide "Agerin Egyptian Journal of Biological Pest Control. 2001. 11: 1/2, 45-49. 11 ref. Egypt

4- Badenes-Perez, F. R., A. M. Shelton. 2006. Pest management and other agricultural practices among farmers growing cruciferous vegetables in the Central and Western highlands of Kenya and the Western Himalayas of India. International Journal Of Pest Management 52:4, 303-315. 49 ref USA.

5- Schwarz, M., D. Christie, W. Andersch, K. Kemper, K. Fellmann, R. Altmann. 2002. Control of corn rootworms (Diabrotica spp.) and of secondary pests of corn (Zea mays) using seed treatments of clothianidin. The BCPC Conference: Pests and diseases, Volumes 1 and 2. Proceedings of an international conference Brighton, UK, 18-21 November. 59-64. 3 ref

6- El-Husseini. 2004. et. al. Isolation, production and use of entomopathogenic fungi for controlling the sugar beet insect pests in Egypt. Proceedings of the 1st Arab Conference for Applied Biological Pest Control, Cairo, Egypt, 5 to 7 April 2004.Center of Biological Control, Fac. Agric., Cairo Univ., Giza, Egypt

7- Finny, D. j. 1952. Probit analysis, 3rd . edition, Campridge University Press, pp. 333.

8- Harris, C. R., J. A. Begg, J. H. K. Mazurf. 1958. A Laboratory Method of Mass Rearing the Black cut warm, Agrotis ypsilon (Rott.), for Insecticide Tests. The Canadian Entmologist, 90: (6) 328-331 Canada.

9-Hill, D.S. 1983. Agrotis ipsilon (Hfn.) In agriculture insect pests of the tropics and their control. Cambridge Univ. press, pp. 357, 746 pages. UK.

10-Mansour, E. S., M. M. Khewa', G. H. Ebaid, S. Z. Sayed. 2005. New approaches for controlling the black cutworm Agrotis ipsilon (Hufn.) (Lepidoptera: Noctuidae . Egypt. Annals of Agricultural Science, Moshtohor. 2005. 43: 1, 485-496. 27 ref . 
11- Mishra, P. N. and M. P. Singh. 2006. Relative efficacy of insecticides against cutworm, Agrotis ipsilon (Hufn.) damaging potato in Western Himalayas. Indian Journal of Entomology. 2006. 68: 4, 380-383. 16 ref India.

12-Muhammad Shakur, Farman Ullah, Muhammad Naem, Muhammad Amin, A. U. R. Saljoqi, Muhammad Zamin. 2007. Effect of various insecticides for the control of potato cutworm (Agrotis ipsilon Huf., Noctuidae: Lepidoptera) at Kalam Swat. Sarhad Journal of Agriculture. 2007. 23: 2, 423-425. 1 ref Pakistan.

13- Sabbour, M. and A. F. Sahab. 2007. Efficacy of some microbial control agents against Agrotis ipsilon and Heliothis armigera in Egypt. Bulletin of the National Research Centre (Cairo). 2007. 32: 5, 559-569. 27 ref Cairo, Egypt.

14-Salama, H. S., S. Salem, F. N. Zaki, M. Matter. 1990. Control of Agrotis ypsilon (Hufn.) (Lep., Noctuidae) on some vegetable crops in Egypt using the microbial agent Bacillus thuringiensis. Anzeiger fur Schadlingskunde, Pflanzenschutz, Umweltschutz. 1990. 63: 8, 147-151. 14 ref Cairo, Egypt.

15-Salama, H. S., F. N. Zaki, S. Salem, M. Ragaei. 1995. The use of Bacillus thuringiensis to control two lepidopterous insect pests (Agrotis ypsilon and Spodoptera littoraís.Anzeiger fur Schadlingskunde, Pflanzenschutz, Umweltschutz. 1995. 68: 1, 15-17. 8 ref Cairo, Egypt.

16-Salama, H.S., S. A. Salem, F. N. Zaki, A. Abdel-Razek. 1999. The use of Bacillus thuringiensis to control Agrotis ypsilon and podoptera exigua on potato cultivation in Egypt. Archives of Phytopathology and Plant Protection. 1999. 32: 5, 429-435. 11 ref Cairo, Egypt.

17- Schwarz, M., D. Christie, W. Andersch, K. Kemper, K. Fellmann, R. Altmann. 2002. Control of corn rootworms (Diabrotica spp.) and of secondary pests of corn (Zea mays) using seed treatments of clothianidin. The BCPC Conference: Pests and diseases, Volumes 1 and 2, 18-21 November 2002, UK.

18- Youssef, H.I. 1997. New approaches for controlling the greasy cutworm, Agrotis ipsilon Huf. and the mole-cricket, Gryllotalpa gryllotalpa Fab. Using alum/insecticides synergism. Annals of Agricultural Science, Moshtohor. 1997. 35: 1, 521-535. 16 ref ARC, Cairo, Egypt 


\section{دراسات مقارنة لإستخدام بعض الطعوم كمواد طبيعية}

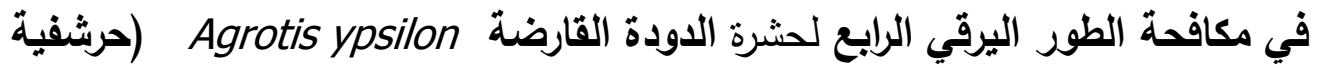
الأجنحة) معمليا وحقليا

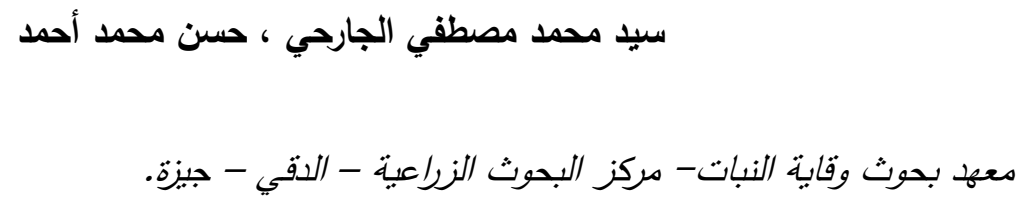

تهدف هذه الدراسة إلي استخدام مادة طبيعية وهي الجير والذي عند تفاعله مع الماء الموجود بالمعدة لحشردو والذي ينتج عنه طاقة كبيرة تؤدى إلي موت الطور الرابع من حشرة

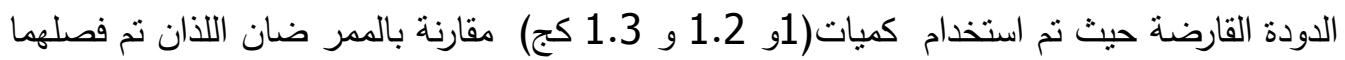

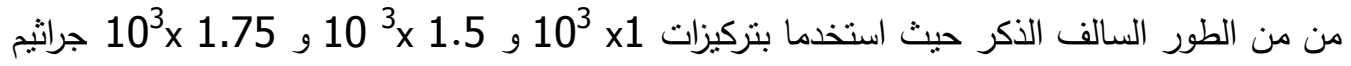

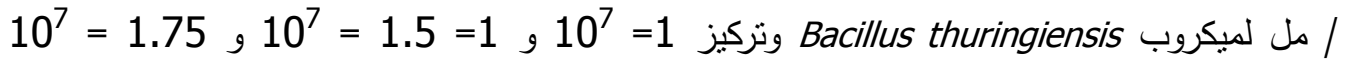
جراثيم / مل لفطر Metarhisium anisopliae مقارنة بالمبيد الكيماوي هوستاثيون بتركيزات (1 1و 1.5

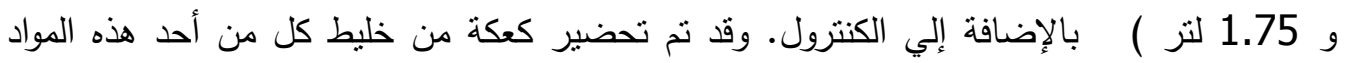

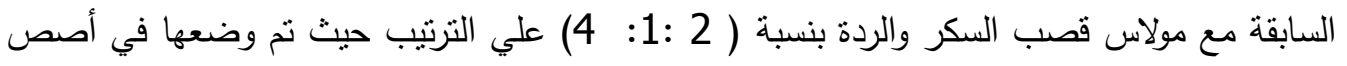
بها نبانات الطماطم في المعل لددة 24 و 48 و 72 ساعة و تم المع التعرف علي كمية المادة المستهكة

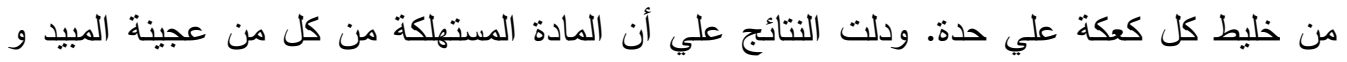

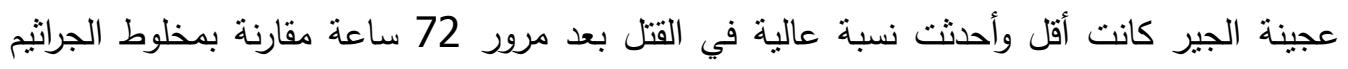

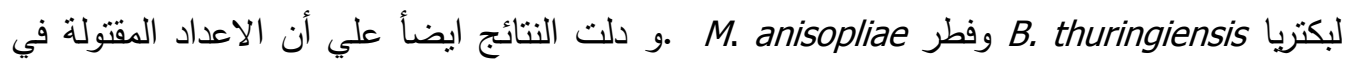

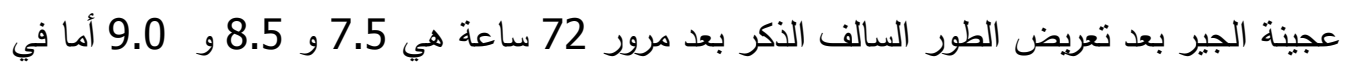
الكنترول0.0 وبحساب الكميات المستهلكة من العجينة وجد أنها 2.6 و 2.0 و 1.5 و 1.5 جرامات مقارنة

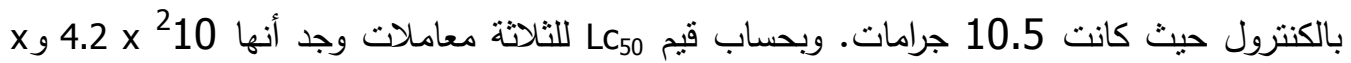
x $4.1 x^{2} 10$

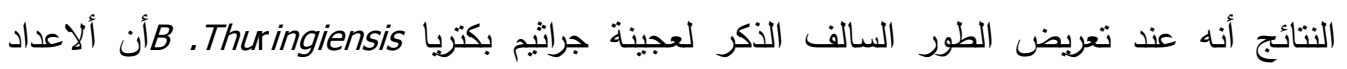
المقتولة بعد مرور 72 ساعة كانت هي 7.5 و 5.0 و 5.0 و 9.0 أما الأعداد المقتولة في الكنترول (00)

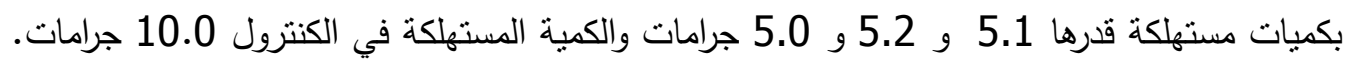

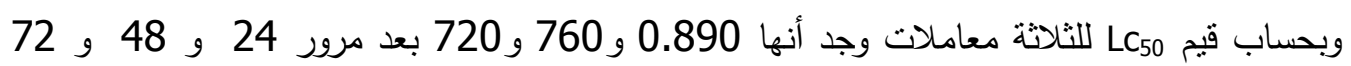

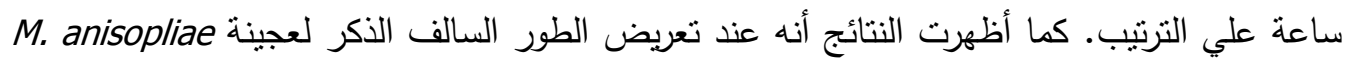

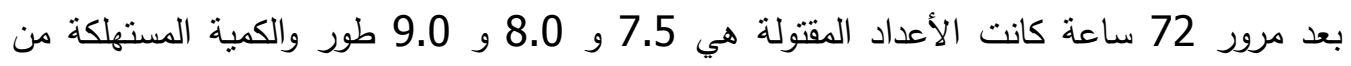

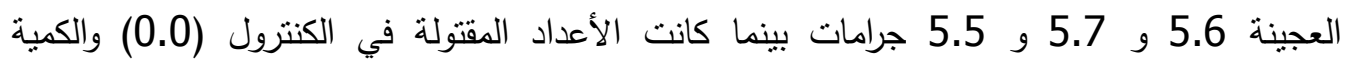

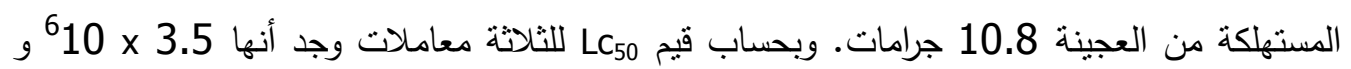

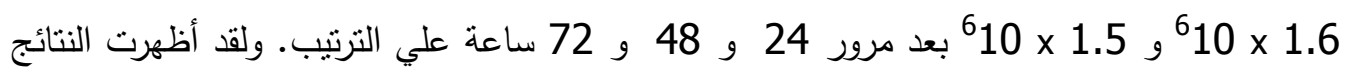


أن الأعداد المقتولة في عجينة المبيد الكيماوي هوستاثيون بعد مرور 72 ساعة كانت الأعداد المقتولة هي 7.5 و 8.0 و 9.0 طور بإستهلاك قدره 2.2 و 1.8 و 1.5 جرامات 5 بينما كانت الأعداد المقتولة في الكونترول (0.0) طور بإستهلاك قدره 10.2 جرامات . وبحساب قيم LC50 للثلاثة

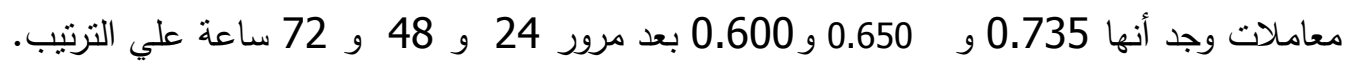

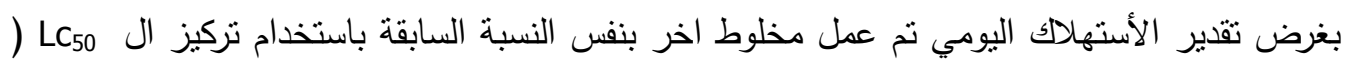
من الأربع معاملات (عجينة الجير و جينة الباسلس و جينة الجير و عجينة المبينة المبيد الكيمبائي

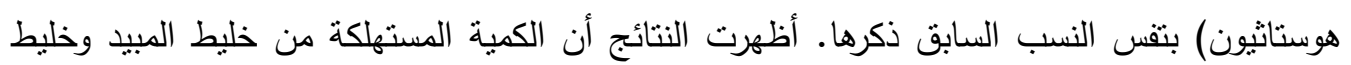
الحير عند أستخدامه بكمية 1.75 كج وهي ( 3.8 جرام بأكبرمعدل للقتل هو 5.4 بعد مرور 72

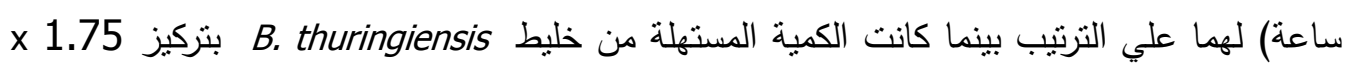

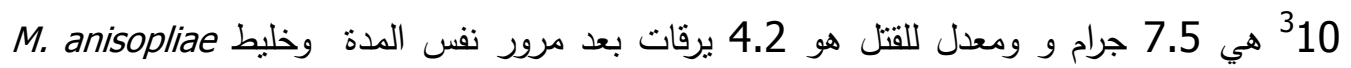

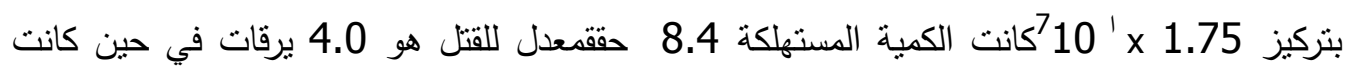
الكمية المستهلكة من كعكة خليط الهوستاثيون بكمية 1.75 لتر هي 2.6 جرامات ومعدل للقتل 4.يرقة هئل بعد مرور 72 ساعة. وتحت الظروف الحقلية دلت النتائج على أن أعلي معدل للقل هو 7.5 يرقات لكل من كعكة مخلوط الجير الحي بتركيز 1.75 كج وخلوط كعكة المبيد الحشري الهوستاثيون بكمية اعلية 1.75 لتر بعد مرور 6 أيام يليها مخلوط كعكة B. B. thuringiensis و مخلوط كعكة

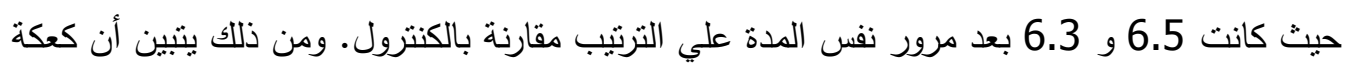
خليط الهوستاثيون وخليط كعكة الجير أدت لأفضل النتائج يليها مخلوط كعكة ميكروب B.thuringiensis ثم مخلوط كعكة M.anisoplia تحت الظروف المعملية والحقلية. 